GENDER STUDIES 20(1)/2021

\title{
sciendo
}

\subsection{8/genst-2022-0002}

\section{PERFORMING PATRIARCHY IN MUCH ADO ABOUT NOTHING}

\author{
PAUL INNES \\ United Arab Emirates University \\ paul.innes@uaeu.ac.ae
}

\begin{abstract}
This article aims to restore the pairing of Claudio and Hero to prominence. The positioning of Hero by Claudio and the play's other powerful men is central to the plotline, especially in terms of the “nothing” of Hero's supposed sexual incontinence, as well as being dramatically pivotal to the play's meanings and structure. The fact that the scene is absent from the play underscores the crucial symbolic importance of the role of Hero to the patriarchal system, drawing attention to the ways in which her function needs to be noted and understood. The analysis undertaken here therefore redresses the balance, since the pairing of Beatrice and Benedick seems so much more alive to modern sensibilities. This article argues that the reason for this lies in their seeming attractiveness as characters who are more easily recuperated to a historically later form of patriarchy from Shakespeare's period, one that resonates powerfully with the rise of individualism to elevate them over Hero and Claudio.
\end{abstract}

Keywords: characterisation, homosocial, patriarchy, performance, Shakespeare.

\section{Introduction}

Claudio seems to be the most boring character Shakespeare ever created. This is because revivals of Much Ado About Nothing since the Victorian period have focused their top billing on the much more interesting, combined pairing of Benedick and Beatrice; Claudio and Hero, by comparison, are inevitably reduced to the sidelines. In the Introduction to her revised edition of the play for the Third Arden Series, Claire McEachern notes the contradiction produced between the performance tradition on the one hand and academic criticism on the other (McEachearn, 2016, pp. 1-2). McEachern's edition first appeared in 2006, five years before the star billing of David Tennant and Catherine Tate effectively proved the editor right: theatre audiences take great delight in the wit and verbal sparring associated with Beatrice and Benedick, while scholars tend towards a more dissatisfied treatment of the peculiar resonances of patriarchy activated by Claudio's rejection of Hero. The current article seeks to negotiate these two positions, finding instead in the play a nuanced and necessary relationship between 


\section{GENDER STUDIES 20(1)/2021}

both couples. This is not to suggest that the pairings are balanced as such - far from it - but that they are both encoded by the exigencies of Renaissance patriarchy in ways that play off one against the other. The combination in performance needs to be addressed as well as each couple separately.

\section{Figures of Renaissance patriarchy}

In terms of the men of the play, it is easy within the parameters given above to assume that Benedick is somehow less patriarchal than Claudio because of the Beatrice effect, and that would seem logical, although rather obviously dull in and of itself. However, one of the most overlooked moments in the play comes after the various introductions are over, and Claudio keeps Benedick behind to talk with him after everyone else has left the stage. What follows is an incredibly precise rendering of the logic of homosocial patriarchy: too little for a great praise. Only this commendation I can afford her: that were she other than she is, she were undhandsome; and being no other but as she is, I do not like her.
} (I.1.154-167)

It is worth unpacking these lines, and indeed the rest of the scene, in detail. Here we have two noblemen discussing the attributes of an absent woman. As Eve Sedgwick realizes when quoting Heidi Hartmann (Sedgwick, 2015, p. 3), this is the defining feature of the very structure of patriarchy:

relations between men which have a material base, and which, though hierarchical, establish or create interdependence and solidarity among men that enable them to dominate women. (Hartmann, 1981, p. 14)

When Claudio holds Benedick back to ask his opinion about Hero, he does so in strict accordance with the patriarchal dictates delineated by Hartmann. The material base is crucial in 
this respect, because of course Hero is that most precious commodity in the patriarchal economy, a wealthy noble heiress or, as Claudio goes on to say, a jewel (I.1.171). And as suggested above, it is of fundamental importance that the woman being discussed should not even be present. In fact, she cannot be so if this performance of patriarchy is to work on the stage - she does not matter in and of herself, since what is really being noted here is what she means to Claudio. This is the first time the word appears in the play, and its doubled use by both men denotes the central importance of what men say about women and, indeed, how they define them. To continue with Hartmann's designation, the hierarchical relationship between these two has already come into existence before the play begins, with their interdependence and solidarity having been created in the broils of a civil war. These are aristocratic soldiers, and it is difficult to think of a pair who would be more fitting for the purposes of the structure in action. The busy beginning of the play is here replaced by a more intense personal conversation between the two noblemen, and the sudden absence from the stage of the other characters reinforces the focus on these two alone.

Although Benedick tries to inject some light-hearted banter into the discussion, he nevertheless remains complicit. Claudio might be the unpleasant face of patriarchy, while Benedick is the more comedic version, but nevertheless the structure is still resolutely patriarchal. Indeed, the play reinforces the emphasis by having Don Pedro return to the stage to see what is going on between the other two:

$\begin{array}{ll}\text { DON PEDRO: } & \text { What secret hath held you here that you followed not to Leonato's? } \\ \text { BENEDICK: } & \text { I would your grace would constrain me to tell. } \\ \text { DON PEDRO: } & \text { I charge thee on thy allegiance. } \\ \text { BENEDICK: } & \text { You hear, Count Claudio? I can be secret as a dumb man; I would have you } \\ & \text { think so. But on my allegiance - mark you this, on my allegiance - he is in } \\ & \text { love. With who? Now, that is your grace's part. Mark how short his answer is: } \\ & \text { with Hero, Leonato's short daughter. } \\ \text { CLAUDIO: } & \text { If this were so, so were it uttered. } \\ \text { BENEDICK: } & \text { Like the old tale, my lord: 'it is not so, nor 'twas not so'; but indeed, God } \\ \text { CLAUDIO: } & \text { forbid it should be so! } \\ \text { DON PEDRO: } & \text { If my passion change not shortly, God forbid it should be otherwise. } \\ & \text { Amen, if you love her, for the lady is very well worthy. (I.1.193-208) }\end{array}$

It is difficult to disentangle the complex nuances of this patriarchal discussion at such a remove, but the effort is well worth making. As King of Spain, Don Pedro is the ultimate authority in this particular structuration, and it is important to note that his comment about her worth 


\title{
GENDER STUDIES 20(1)/2021
}

replicates Claudio's earlier evaluation of "the lady" as a jewel - and Don Pedro does not even bother to use her name, at least not yet. The deployment of the language of hierarchy, while easily laughed off in performance, nevertheless gives the whole business a serious underpinning. It is also crucial to note that Claudio utters a critical line when he effectively says that all will be well so long as his passion does not change.

After some more banter, Benedick takes his leave, and the system gets to work as the delivery shifts from prose to poetry. The value of the woman is what is at stake here, so let the horse-trading commence:

DON PEDRO: $\quad$ No child but Hero, she's his only heir. (I.1.275-6)

Shakespeare is here still harping upon heiresses, and it should be remembered just how many of them there are in his plays - and how attractive they are to wealthy, entitled young men as a result. The upshot is the first of many stratagems deployed in the play as people try to manipulate one another, while often failing:

\author{
DON PEDRO: I know we shall have revelling tonight; \\ I will assume thy part in some disguise \\ And tell fair Hero I am Claudio; \\ And in her bosom I'll unclasp my heart \\ And take her hearing prisoner with the force \\ And strong encounter of my amorous tale. \\ Then after, to her father will I break, \\ And the conclusion is: she shall be thine. \\ In practice let us put it presently. (I.1.301-9)
}

This play famously comes close to tragedy, so these lines can be delivered with some menace: "she shall be thine". This is the King of Spain speaking, and he brooks no dissension, as indeed has been demonstrated by his use of force before the play even begins. The decision point is astonishingly clear: it does not matter what Hero might think about all of this, or even what her father might think, because it has been decided that Claudio will gain possession. And still the woman is absent. 


\section{GENDER STUDIES 20(1)/2021}

\section{When is a character not a character?}

Alan Sinfield asks this question when he poses it as the heading for a chapter on Shakespeare's heroines in Faultlines (Sinfield, 1992, pp. 52-79). He is interested in the dilemma posed by the likes of Lady Macbeth and Desdemona for a form of character criticism that assumes these stage personages can be pretty much treated like real people - and, moreover, that believes in (and indeed privileges) consistency and coherence. These are not the only Shakespearean women Sinfield mentions in this chapter, but they do form the main crux of the matter for him. This is because they both seem initially to act so powerfully in and of themselves in their respective plays, but are then marginalised or reduced in stature when they are no longer required to be quite so active by the plotline. It would be a relatively simple matter to follow up on Sinfield's observations by means of a properly Aristotelian analysis of the strictly secondary nature of characterisation, following the comments in Book VI of the Poetics (Aristotle, 1983). However, that is not the purpose of the present discussion, mainly because, in formal terms, Much Ado About Nothing is not a tragedy.

Nevertheless, Sinfield's discussion is still pertinent, because he pinpoints a character function that more or less approximates the effect of a real personage, albeit for short performance moments only, and most definitely in an inconsistent manner. In other words, Sinfield is analysing exactly the same terrain that is the groundwork for the characterisation of figures such as Claudio, Benedick and Don Pedro. Again, when is one of these characters not really a character? Or, to put it differently, at what point can we differentiate between these figures in the terms that seem so obvious to theatre audiences who seem automatically to perceive Benedick and Beatrice as just so much more interesting and alive - more realistic, even - than Claudio and Hero?

Claire McEachern may well be correct when she notes that the emergence of Benedick and Beatrice as the couple with primacy can be dated to the $19^{\text {th }}$ century, and that should give us pause for thought. This is the period that also introduced the world to the Romantic conception of the great creative genius, as well as Freudian patriarchy. These two conceptions share a concern with the primacy of the individual. Or to put it another way, it should not be surprising to find an element like this in the period of the consolidation of the rise of individualism. This is the immediate context for the Victorian validation of Benedick and Beatrice that has continued through the twentieth century and into the twenty-first; it is hardly neutral and it is also in its own terms patriarchal. These two characters seem more naturally 


\section{GENDER STUDIES 20(1)/2021}

realistic within a constructed system, and really should not be considered separately from that structure. The hierarchical superiority allocated to them is overdetermined.

Terms like "naturally realistic" gesture towards the necessity for some form of ideological critique, because of course the system that privileges Beatrice and Benedick over Hero and Claudio is neither natural nor realistic; it is historically contingent. Lying behind it is the formulation of a sense of selfhood associated with the likes of Coleridge and Wordsworth, and the latter's inability to complete an epic poem about the emergence of bourgeois subjectivity speaks volumes, as does the former's inability to complete poems. In historical terms, the middle-class self just is not very interesting, and it is certainly not epic: such a bastion of mediocrity surely cannot be trusted when it comes to the formulation of a criticism of Shakespearean drama.

One rather obvious way to look at Beatrice and Benedick, then, is to note that their seemingly superior interest-value derives directly from their being made to fit a system that emerges historically much later than Shakespeare's play - and at one level this makes the extreme importance accorded to their pairing ahistorical. Two fundamental implications emerge from this logic. The first is that it therefore should be possible to analyse Benedick's role in Renaissance patriarchy, which is in fact why this essay has spent so much time on his early conversation with Claudio. The second, of course, is to understand the double structuration of the play itself, since Claudio's role is central. The implication here is that neither couple is in fact privileged over the other in Shakespeare's play, and certainly not when compared with the later impositions just described.

An obvious, but rather simplistic way to do this, would be to characterise Beatrice and Benedick in terms of their performative elements, with Hero and Claudio relating more to the play's structure due to the importance of Hero's "nothing". However, this misses the subtleties of Shakespeare's dramatic constructions, since Claudio and Hero have their own moments of prevalence in performance, and Beatrice and Benedick similarly have structural roles to play. One would not wish to reconstruct yet another binary opposition that could easily be taken apart.

\section{The conventionality of Claudio and Hero}

Just before he agrees to woo Hero on Claudio's behalf, Don Pedro comments wryly that: 


\section{GENDER STUDIES 20(1)/2021}

DON PEDRO: $\quad$ Thou wilt be like a lover presently

And tire the hearer with a book of words. (I.1.287-8)

The statement is a reference to the courtly love tradition, especially as associated with the contemporary vogue for sonnet sequences. The ease with which Don Pedro relates Claudio to this set of conventions suggests that Claudio's position is itself predicated as purely conventional. A good example comes when he is easily fooled by Don John into thinking that Don Pedro has in fact gained Hero for himself:

DON JOHN:

Signor, you are very near my brother in his love. He is enamoured on Hero. I pray you, dissuade him from her, she is no equal for his birth. (II.1.148-150)

Not only does this foreshadow the later events of the play, but it also reinforces the importance of rank in this society. A later form of criticism would be tempted to say that Claudio thinks in conventional terms; a more sophisticated formulation would be that this stage fiction functions to represent a historically and culturally specific subject position. A contemporary Renaissance audience's interest will be activated by the play's nuanced use of courtly love in the figure of Claudio, which suggests that on his own stage, this figure would have commanded much more attention than is given him by later cultures. The significance of this manoeuvre is that it restores some semblance of performative power to Claudio.

Hero also has her moments. When she leads the women's part in the plotting to bring Beatrice and Benedick together again, she is extremely effective, which would suggest that there are some grounds for considering her to be much more than emptily anodyne. The set scenes where Claudio is one of a group of men who manipulates Benedick (II.3) is dramatically patterned with the following scene in which Hero takes the lead in gulling her cousin (III.1). The paired nature of the scenes draws attention to stage artifice, and so should not be dismissed out of hand - such self-aware artificiality being a major component of Renaissance drama. The work of Robert Weimann, especially his theorising of what he calls the Figurenposition, discusses such possibilities available on the Renaissance stage (Weimann, 1978, pp. 224-36). Structurally and in performance, accordingly, Hero can act very powerfully. Now of course she is authorised to do so by the men in the play, but even so her success is predicated upon an ability to be disturbingly active, albeit within a carefully circumscribed sphere of operations. This is exactly the sort of situation that Shakespeare later explores with the figure of Hermione in The Winter's Tale, another play that comes very close to tragedy. For a woman to be 


\section{GENDER STUDIES 20(1)/2021}

successful at all in such an activity threatens to undo the most basic premise of patriarchy: that women are essentially passive.

\section{Hero's nothing}

Although Hero's nothing does not actually appear directly in the play, the men nevertheless make a great deal out of it - and of course the old Renaissance pun is salutary. What this does is concentrate the audience's attention on the meanings associated with the absence at the centre of the play, doubly so since they do not see the scene directly. It also means that they do not themselves perceive or apprehend the men's immediate reactions; the way the play is structured at this point denies the audience the possibility of watching the watchers, something that is common in other moments in the performance. Shakespeare is not just varying the terms and techniques of the exposition for the sake of it. What matters in this instance is not what the audience sees, but what they hear - the multiple definitions given to the event by other characters, none of which is disinterested. This reinforces the ways in which discourse is used as a vehicle for definition and indeed showcases exactly how this operation takes place.

There is, of course, another possible performance twist that is not catered for by the tradition of textual editing, and her name is Innogen. Usually excised from the play because she does not speak, Hero's mother is considered to be a "ghost" character who was originally written in by Shakespeare but then forgotten about in the heat of composition. Structurally and visually, then, her presence prefigures and embodies what will happen to both Hero and Beatrice at the end of the play. Not to take advantage of such a possibility is a thoroughly missed opportunity. As Terence Hawkes notes, the presence of a woman muzzled by marriage must surely carry extra resonances for a play that ends with both of the main female characters silenced in the way McEachern realises is such an issue for textual scholarship - and by extension, for critical interpretation also (Hawkes, 1992, p. 156 n.9). If Innogen is present at various points in the play as a "masked", silenced woman, then in visual terms she is joined by Beatrice and Hero at the end as the result of an operation of power.

There is no need here, though, to rehearse the multiply ironic way in which the useless constables arrest Borachio and Conrade after the supposed deed is done, nor is there any need to look at Claudio's language when he repudiates Hero at the altar. Lisa Jardine provides an analysis of the social consequences of such public shaming of important high status personages in the case of Othello (Jardine, 1996, p. 33). What does matter, however, is how all of the men 


\section{GENDER STUDIES 20(1)/2021}

try to discern Hero's guilt or innocence in an exceptionally precise rendering of the male gaze or, to put it more precisely, the patriarchal gaze. The reference to Laura Mulvey's (1999) ground-breaking concept is, however, a partial one. Her essay entitled "Visual Pleasure and Narrative Cinema" genders the cinematic gaze as male precisely because she is interested in a much later form of patriarchy. She argues that the singular viewpoint of the camera creates a monolithic perspective that is fundamentally associated with the masculine prerogative. This is not the case for a Shakespearean audience as opposed to the modern viewer (or voyeur) because Renaissance English public playhouses afforded multiple perspectives due to the amphitheatre layout of the buildings. In another sense, the Renaissance audience is not singular because as well as multiple perspectives, it is composed of people from widely differing social strata and genders. However, it is worth noting that all of the actors on the stage gazing at Hero's supine body after she faints are men, including the women - and Hero is a man too. The split between actor and role is intensified by the precise rendering of the situation. As with Desdemona, the public shaming of a female character emblematises the effects patriarchy has on women's bodies.

Don Pedro and Claudio are of course fooled into believing that Hero has been unfaithful, but so too initially are the other men. Even Leonato, her father, thinks so and, revealingly, he is the one who is given the lines that set up the print metaphor:

LEONATO:

Could she here deny

The story that is printed in her blood? (IV.1.121-2)

It takes the friar's intervention to read the truth in her innocence as he also treats her almost like a book, so correcting the misreading. He reads her "nothing" correctly.

It might seem strange to note this, but it is not so much the supposed "seduction" scene or the repudiation that reduces the importance of the Claudio/Hero couple, so much as the way Claudio behaves when he realises the truth and is fooled into recanting. It is the movement towards the end of the play that cements the hierarchical importance of Beatrice and Benedick in the eyes of later audiences; it just seems so "natural", and there is that word again. If it seems natural, then it probably is not. Later audiences just do not understand why Hero would agree once again to marry this man after everything he has said and done. And herein lies the rub: to build upon Alan Sinfield's observation, these are not real people, but dramatic fictions, and they function to represent specific subject positions. Or, following Aristotle, the plot's the thing. 


\section{GENDER STUDIES 20(1)/2021}

This rather more formalistic, abstracted language provides a set of tools that enables a more historically and theoretically aware analysis of the play's problematic ending. The reason for this is that it avoids falling into the trap laid for us by the $19^{\text {th }}$-century's refigured reception of the play, which must be based on feelings of sympathy for what are assumed to be more fully rounded, realised individuals - people, in fact. Beatrice and Benedick are simply made to appeal more "realistic" to the sensibilities of the Romantics and Victorians. It is always difficult to keep in mind the fact that these stage personages are fictions, but this allows us to conceptualise them more in line with how they function on their own stage which, after all, predates the triumph of the bourgeois individual by several centuries. Beatrice and Benedick are constructs just as much as Claudio and Hero.

\section{Benedick the patriarch}

As noted above, it is Benedick's relationship with Beatrice as the play moves towards its conclusion that makes their pairing seem superior. However, two important caveats need to be inserted here. First of all, the resumption of their relationship is predicated upon paired sets of lies perpetrated by their so-called friends. And, secondly, it makes Benedick party to the plotting to force Claudio and Don Pedro to make up for the damage they have caused by a ritualistic form of public recantation. It depends for its force on the truth coming out about what really happened the night before the wedding was supposed to take place, but it is also an exceptionally complex form of gulling in its own respect. Claudio is made to swear to marry whoever is chosen for him as recompense for what has happened to Hero, and he agrees:

$\begin{array}{ll}\text { LEONATO: } & \text { Good morrow, Prince, good morrow, Claudio. } \\ & \text { We here attend you. Are you yet determined } \\ & \text { Today to marry with my brother's daughter? } \\ \text { CLAUDIO: } & \text { I'll hold my mind were she an Ethiope. (V.4.35-39). }\end{array}$

And here we have one of those points of racist reference that are so common in texts from the period. Claire McEachern is the first Arden editor to provide a gloss at all:

Ethiope i.e. an Ethiopian, foreign in both nation and race; therefore unattractive. The OED (Ethiop) lists a possible derivation from the Greek for 'to burn' + 'face' = burnt-face, 'later sunburnt'. Cf. 2.1.292-3: 'Thus goes everyone to the world but I, and I am sunburnt.' (McEachern, 2016, p. 350 n. 38) 


\section{GENDER STUDIES 20(1)/2021}

But the full meaning of Claudio's phrasing is much extreme: the racist typology is a clear statement that he will do the worst thing he can possibly imagine if it comes to it, and for him and his society, the worst is black. Shakespeare's play therefore registers a fundamentally racist register as one of the constitutive elements of Renaissance patriarchy, something that has been noted in relation to Shakespeare scholarship quite recently by Ayanna Thompson:

\footnotetext{
At the same time, the editions of Shakespeare's plays I was reading routinely fell silent at certain moments. Claudio's rejoinder in Much Ado About Nothing that he is so repentant over Hero's death that he will do anything to marry her cousin, even "hold my mind were she an Ethiope" (5.4.38), receives no gloss in the Arden Second Series edition published in 1981. (Thompson, 2021, p. 1)
}

The kind of phrasing uttered here by Claudio is most likely to underscore the many reasons why he is disliked by later audiences, but again it must be stressed that this is not a person speaking, but a stage figuration, a dramatic construct. And here he functions to represent a central element of the Renaissance social hierarchy; after all, you don't build an empire if you respect other cultures.

Benedick figures forth this patriarchal culture just as much as Claudio does. It has to be remembered that, when he helps Hero's family towards the end of the play, they are all working towards the same goal: to get Hero and Claudio married, regardless of what he has done to her. It is astonishing to think that such a scheme should somehow be seen as positive in terms of an audience's response, but of course what happens is that it is all personalised, reduced to Hero's individual response: why would she still want to marry this man? The question should instead be: why is everyone so determined to make sure the play ends with her marrying this man? And why is this much more serious question not being asked? As Barbara Everett terms it, this play is the "unsociable comedy" (Everett, 2001, pp. 51-68).

Perhaps its salience is easily lost in the series of improbable scenes with which the play finishes, effectively as one element among many others - there is just so much going on here. Claudio's reply goes without comment from any of the other characters, as though it is "natural", which should give us pause for thought. Again, it is not so much that these "people" think in this way, as these stage fictions function to represent certain subject positions, and in this respect they are all complicit - to use that word again - by means of their silence on the matter. The same logic must be applied to the patriarchal ending of the play, and Benedick's role in it is salutary. Not only is a series of masked or veiled (and so conventionally silenced) 


\title{
GENDER STUDIES 20(1)/2021
}

women presented, but two of them are married off to Benedick and Claudio almost as though nothing has happened - which surely is the underlying pun here.

The textual history of the play poses a further problem, and it gets right to the nub of what is going on with Benedick. As Claire McEachern notes:

\begin{abstract}
SP Q's assignment of this speech to Leonato (rather than to Benedick, as in most editions after Theobald) is in keeping with his characteristic attempts to stage-manage this scene, and his role as Beatrice's guardian; it also provides for a more egalitarian accommodation between the lovers than would Benedick's own declaration of intent to silence Beatrice, and egalitarianism which seems in keeping with the tenor of their relationship throughout. (Peace could in fact be delivered to both of them.) As a directive delivered by a third party to a couple, it has the precedent of Beatrice's command to Hero at 2.1.285-6, to 'Speak, cousin, or, if you cannot, stop his mouth with a kiss and let not him speak neither.' Leonato's statement (and accompanying gesture indicated in this edition's SD2) need not imply that Benedick kisses Beatrice (though most editions signal as such), but merely that in handing Beatrice over to Benedick (as Leonato is entitled to do, being both her uncle and guardian) he will silence her merely by getting her a husband. (McEachern, 2016, p. 354 n. 97)
\end{abstract}

There are many good reasons for quoting this long notation in its entirety - its length in fact denotes that the editorial tradition has some issues with this part of the scene. McEachern tries to cover all the performance potentialities, but given that so much has taken place since the earlier foreshadowing references she detects, a similar repetition of terms at this late stage is inevitably going to be modified. Silencing a woman "merely by getting her a husband" seems to need strengthening as a formulation, because the marriages with which this play ends are in effect both forced, not egalitarian: Beatrice and Benedick because they have been tricked into it, and Hero and Claudio because the patriarchy demands it, as indeed does the ritualistic, formal ending required by the supposedly comedic form. Indeed, it is possible to go further than this because, if Theobald's instincts (and those of subsequent editors) are right, then the performance moment requires it to be Benedick who "stops" Beatrice's mouth: marriage does not "merely" get her a husband, it subjects her to the patriarchal will. A good example of another way to think of the play's structure and ending is provided by Jean Howard in terms of theatrical practice (Howard, 2001, pp. 103-122). She draws attention to the ways in which the play points to its own denouement even as it stages it. In other words, this play's ending is a variation on the common Renaissance dramatic incorporation of self-referentiality, a procedure that is so well known from structural elements such as the play within the play as well as references to play-acting as itself a source of figurative allusion. 


\section{Conclusion}

Within the structure of Much Ado About Nothing, therefore, Benedick is not at all different from Claudio because they are both patriarchal constructs and their respective marriages dramatize their power in action. Hero and Beatrice are both, in turn, also patriarchal constructs; as masculine embodiments of the meanings ascribed to women they are constantly subjected to scrutiny. Indeed, this is not limited to the men of the play, since they both comment repeatedly on each other in ways that draw attention to the play's incessant circulation around the terrain of Hero's "nothing". It would be tempting to describe the play as a failed masculine attempt to fill up that nothing of femininity. At the very least, this particular Shakespearean comedy dramatizes patriarchy in action, its unlovely posturing delineated with incisive precision.

\section{References}

Aristotle (1983). On the Art of Poetry. In T.S. Dorsch (Ed.). Classical Literary Criticism. Penguin Books.

Everett, B. (2001). Much Ado About Nothing: The Unsociable Comedy. In M. Wynne-Davies (Ed.). Much Ado About Nothing and The Taming of The Shrew (pp.51-68). Palgrave Macmillan.

Hartmann, H. (1981). The unhappy marriage of Marxism and Feminism: Towards a more progressive union. In L. Sargent (Ed.). Women and Revolution: A Discussion of the Unhappy Marriage of Marxism and Feminism (pp.1-41). South End Press.

Hawkes, T. (1992) Meaning By Shakespeare. Routledge.

Howard, J. (2001). Antitheatricality Staged: The Workings of Ideology in Shakespeare's Much Ado About Nothing. In M. Wynne-Davies (Ed.). Much Ado About Nothing and The Taming of The Shrew (pp.103-122). Palgrave Macmillan.

Jardine, L. (1996). Reading Shakespeare Historically. Routledge.

Mulvey, L. (1999). Visual Pleasure and Narrative Cinema. In S. Thornham (Ed.). Feminist Film Theory: A Reader. Edinburgh University Press.

Sedgwick, E. (2015). Between Men: English Literature and Male Homosocial Desire. Columbia University Press. Shakespeare, W. (2016). Much Ado About Nothing. C. McEachern (Ed.). Bloomsbury.

Sinfield, A. (1992). Faultlines: Cultural Materialism and the Politics of Dissident Reading. Oxford University Press.

Thompson, A. (Ed.). (2021). The Cambridge Companion to Shakespeare and Race. Cambridge University Press. Weimann, R. (1978). Shakespeare and the Popular Tradition in the Theater: Studies in the Social Dimension of Dramatic Form and Function. Johns Hopkins University Press. 


\section{GENDER STUDIES 20(1)/2021}

Paul INNES, PhD, is Professor of English Literature at the United Arab Emirates University. His main interests are in Shakespeare and Critical Theory. He is the author of four books about Shakespeare's plays and poems, and another on the Epic. He has published articles on these and related topics in many journals and has taught previously in Poland, Scotland and England. 